\title{
Geomorphological Processes at the Industrial Sludge Landfill in Sered, Slovakia
}

\author{
Eva Michaeli ${ }^{1, *}$, Matúš Maxin ${ }^{1}$, Vladimír Solár ${ }^{1}$, Jozef Vilček ${ }^{1}$ and Martin Boltižiar ${ }^{2,3}$ \\ 1 Department of Geography and Applied Geoinformatics, Faculty of Humanities and Natural Sciences, \\ University of Prešov, 17. Novembra 1, 08001 Prešov, Slovakia; matus.maxin@smail.unipo.sk (M.M.); \\ vladimir.solar@unipo.sk (V.S.); jozef.vilcek@unipo.sk (J.V.) \\ 2 Department of Geography and Regional Development, Faculty of Natural Sciences, Constantine the \\ Philosopher University in Nitra, Trieda A. Hlinku 1, 94901 Nitra, Slovakia; mboltiziar@ukf.sk \\ 3 Institute of Landscape Ecology, Slovak Academy of Sciences, Bratislava, Branch Nitra, \\ Akademická 2, 94901 Nitra, Slovakia \\ * Correspondence: eva.michaeli@unipo.sk
}

Citation: Michaeli, E.; Maxin, M.; Solár, V.; Vilček, J.; Boltižiar, M. Geomorphological Processes at the Industrial Sludge Landfill in Sered, Slovakia. Sustainability 2021, 13, 6605. https://doi.org/10.3390/su13126605

Academic Editor: Antonio

Miguel Martínez-Graña

Received: 17 May 2021

Accepted: 8 June 2021

Published: 9 June 2021

Publisher's Note: MDPI stays neutral with regard to jurisdictional claims in published maps and institutional affiliations.

Copyright: (c) 2021 by the authors. Licensee MDPI, Basel, Switzerland. This article is an open access article distributed under the terms and conditions of the Creative Commons Attribution (CC BY) license (https:// creativecommons.org/licenses/by/ $4.0 /)$.

\begin{abstract}
The principal aim of the study is to identify the nature and causes of changes to the surface of a landfill body of waste from nickel production located in the industrial zone of the town of Sered' (Slovak Republic). This change is related to natural and anthropogenic geomorphological processes characteristic of the temperate zone of the northern hemisphere. The landfill is an accumulative anthropogenic form of relief, and its body is composed from an artefact-metallurgical sludge, which has specific properties. The landfill constitutes a strange shape of relief at the Danubian Plane, which attracts attention with its physiognomy and also with the black color of the material significantly. It formed during the 30-year-long existence of the nickel smelter plant (1963-1993) and remained in this location, until the present day, for another 28 years after the end of production. Since 1994, the landfill has been the property of a private company that mines sludge in order to obtain residual metals.
\end{abstract}

Keywords: landfill; metallurgical sludge; mass wasting processes; eolian processes; slope water erosion processes; anthropogenic processes

\section{Introduction}

The aim of the article was to find out which geomorphological processes are currently taking place in the landfill and the origin of which forms of relief they conditioned. We also relied on our previous research, but the most important was direct field research, associated with relief forms mapping. Our contribution to anthropogenic geomorphology lies primarily in the identification of geomorphological processes at the metallurgical sludge landfill. These processes have been degrading the environment for 58 years and damaging the health of the population, so we wrote this article.

Although research into anthropogenic shapes of relief has, until recently, been a secondary problem of global geomorphological research, today, it is a scientific topic that is resonating in some regions, particularly in Central and Eastern Europe. Anthropogenic geomorphology deals with the entire array of problems related to anthropogenic forms of relief (man-made forms of relief), starting with classification and moving on to mapping, research into their development, and the geo-ecological applications of the acquired knowledge [1]. The share of human activities in the formation of the relief of the Earth's surface is currently equally significant compared to other geomorphological processes. Humans are an important component of processes involved in the evolution of the shapes of relief in landscapes [2].

Anthropogenic geomorphological processes and the shapes of anthropogenic relief are, at present, one of the more significant phenomena in the lithosphere, and they are related to the scientific and technical development of human society, guided by its economic, 
social, and cultural needs $[1,3]$. Geomorphological research proves that the annual direct production of anthropogenic sediments from the total quantity of sediment in 2015 was approximately $316 \mathrm{Gt}\left(150 \mathrm{~km}^{3}\right)$, which is 24 times greater than the sediments brought annually by the world's major rivers to the oceans [2].

At the local or regional level, the anthropogenic shapes of relief may be very significant, e.g., residential terraces, communications and adjacent areas, industrial complexes, water reservoirs, areas where the mining of raw materials is taking place, etc. The quantity and diversity of the anthropogenic form of relief in the landscape directly depends on the population growth, with regard to satisfying basic life needs (e.g., the production of energy, processing of raw materials, etc.). We may assume that the diversity and number of the anthropogenic shapes of relief will increase, especially in the future, and thus their effects on landscape structure and the environment will become even more important. The anthropogenic forms of relief represent mainly artificial but also semi-natural elements in the landscape that can disturb its dynamic balance. These elements cause changes in the circulation of substances in the landscape and support the formation and circulation of new artificial substances, thus changing the quality of the atmosphere, surface, and underground waters, the nature of soils, vegetation cover, and the quality of life of the population.

The idea of an anthropogenic impact on the relief of the Earth's surface is not novel. In the second half of the 19th century, Marsh (an American scholar) published a book: Man and Nature or Physical Geography Modified by Human Action (first edition published in 1846). Marsh's work was one of the first in which the author deals with the impact of human activity on the environment, and his views helped put into practice the modern protection of nature and the landscape. The book questions the opinion about the inexhaustibility of natural resources, as well the idea that the impact of man on the environment is negligible.

The domain of anthropogenic geomorphology lies in the research of the anthropogenic shapes of relief that arose due to anthropogenic geomorphological processes on the Earth's surface and under it. Anthropogenic geomorphology does not comprise a mere classification and description of these shapes of relief, it also involves studying the processes that led to their origin. At the same, it examines the anthropogenic and natural geomorphological processes currently under way on their surfaces (in a given morphoclimatic zone) and proposes how to eliminate the adverse impact these shapes can have on the environment $[1,3]$.

Publications dealing with the anthropogenic shapes of relief can be divided roughly into four groups. The first group represents the textbooks of geomorphology that contain only a chapter devoted to the anthropogenic shapes of relief (e.g., Klimaszewski [4], Demek [5], Lacika [6], Dzurovčin [7], Goudie [8], Migoń [9], etc.). The second group represents textbooks about the shapes of anthropogenic relief (e.g., Kirchner and Smolová [10], Hronček et al. [11], Čech and Krokusová [12], etc.). The third group represents the studies focusing on regions of the occurrence of the anthropogenic forms of relief of a certain type. This group includes, for example, the work of Fels [13], who used the term "anthropogenic geomorphology" for the first time in the German literature. It also includes the works of Podgórski [14], Michaeli and Boltižiar [15] Hronček [16], Remondo et al. [17], Szabó, Dávid and Lóczy [1], Michaeli et al. [18] Szypula [3], etc.

\section{Materials and Methods}

During the first stage of the research, we determined the geographical position of the landfill within the geomorphological unit [19] of the Danubian Lowland and, subsequently, the physiognomy and the size of the surface, the volume, the age, and the character of the material. During our field research of the territory, we identified the spatial structure of the surface of the landfill and the natural spatial structure of its surroundings.

In the second stage, we elaborated two schemes for the development of the individual sludge field of the tailing pond in the years 1978 and 1988 from maps at the scale 1:10,000 in order to better comprehend the current shape of the surface of the landfill. To create the digital model of the landfill, photogrammetry using a drone with a camera was used. 
Subsequently, we identified the prevailing geomorphological processes and created the map of basic forms of relief. We then processed photographic material from the UAV camera and compared it with the digital model of the relief and the results of our field research, thus creating the basis for the map of the relief of the landfill.

The third stage consisted of detailed field research, during which we focused on mapping the individual microforms of relief. In this phase, we mapped the carving of the relief and its configuration of the classical research methods and created a map of individual forms of relief for the time horizon 2019.

\section{Geomorphological Processes}

In accordance with the classification of the anthropogenic shapes of relief, we take into account all aspects belonging to the landfill of metallurgical sludge in Sered' to classify them into the groups of industrial anthropogenic shapes of relief $[1,6,9,12,20]$.

\subsection{Study Area}

The landfill of metallurgical sludge from nickel and cobalt production by the former smelter plant in the town of Sered' is located in the Danubian Plane on the floodplain of the Váh River in the northernmost part of the Danubian Lowland at an altitude of $125 \mathrm{~m}$ (Figure 1). The landfill represents the waste from the processing of poor lateritic iron-nickel ore from Albania (Ni 1\%, Co $0.055 \%$ per ton of ore). This generated a large amount of waste (annually, 300,000 tons, and the volume of the landfill reached 9 million tons over 30 years). Metallurgical sludge is the by-product of the anthropogenic metamorphosis of Albanian lateritic iron-nickel ore. It is an anthropogenic sediment, with an absolute age of 58 years, and it has specific physical properties that affect the nature of geomorphological processes and, subsequently, the shapes of relief. From the beginning of production in 1963 until its termination in 1993, metallurgical sludge has gradually massed in individual sludge fields on the tailing pond. The relative heights of sludge fields in the tailing pond were from 20 to 80-100 m in 1993. In comparison with the flat relief of the Danubian Plane in the Danubian Lowland, the landfill's relief appears to have a bizarre shape (Figure 2). The origin of the sludge and its properties and the shape of the landfill markedly differentiate this artificial form of relief from the surrounding lowlands landscape. The landfill of waste is the surface bearing of secondary raw materials today (Figure 3).

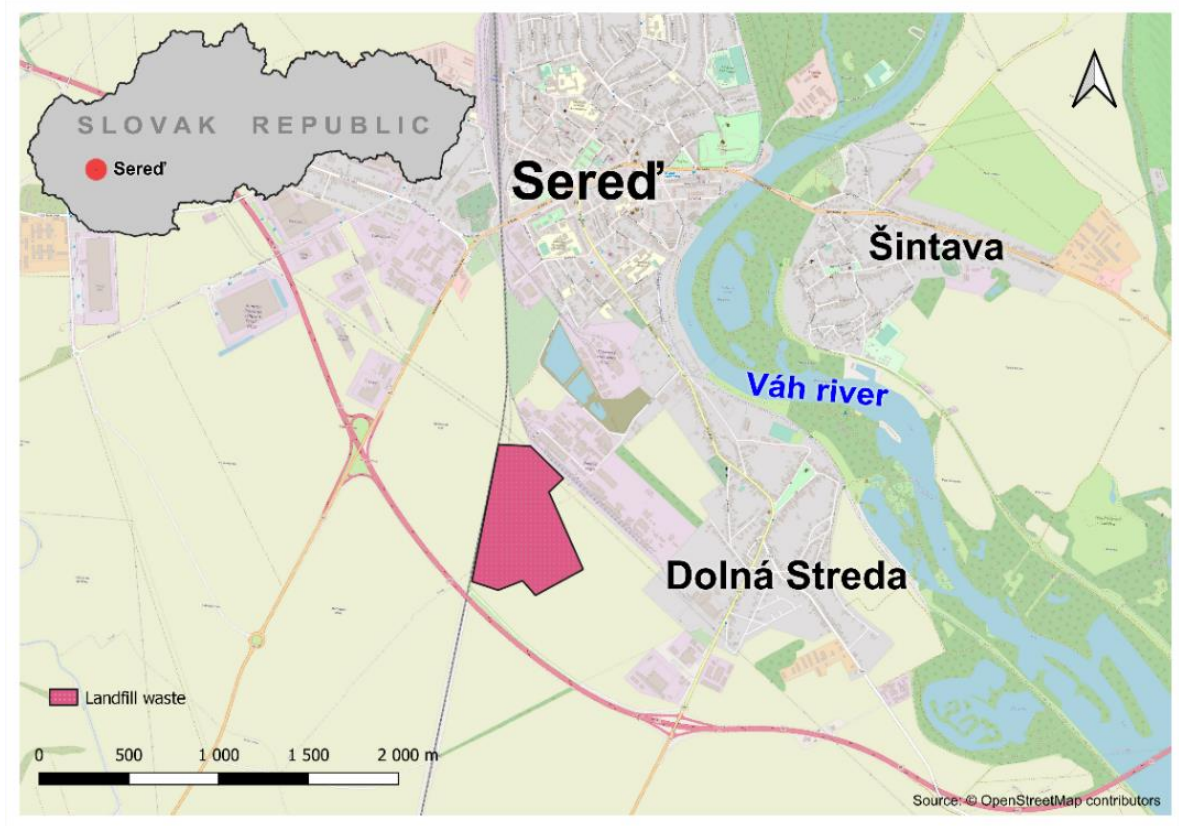

Figure 1. Geographical position of the landfill. 


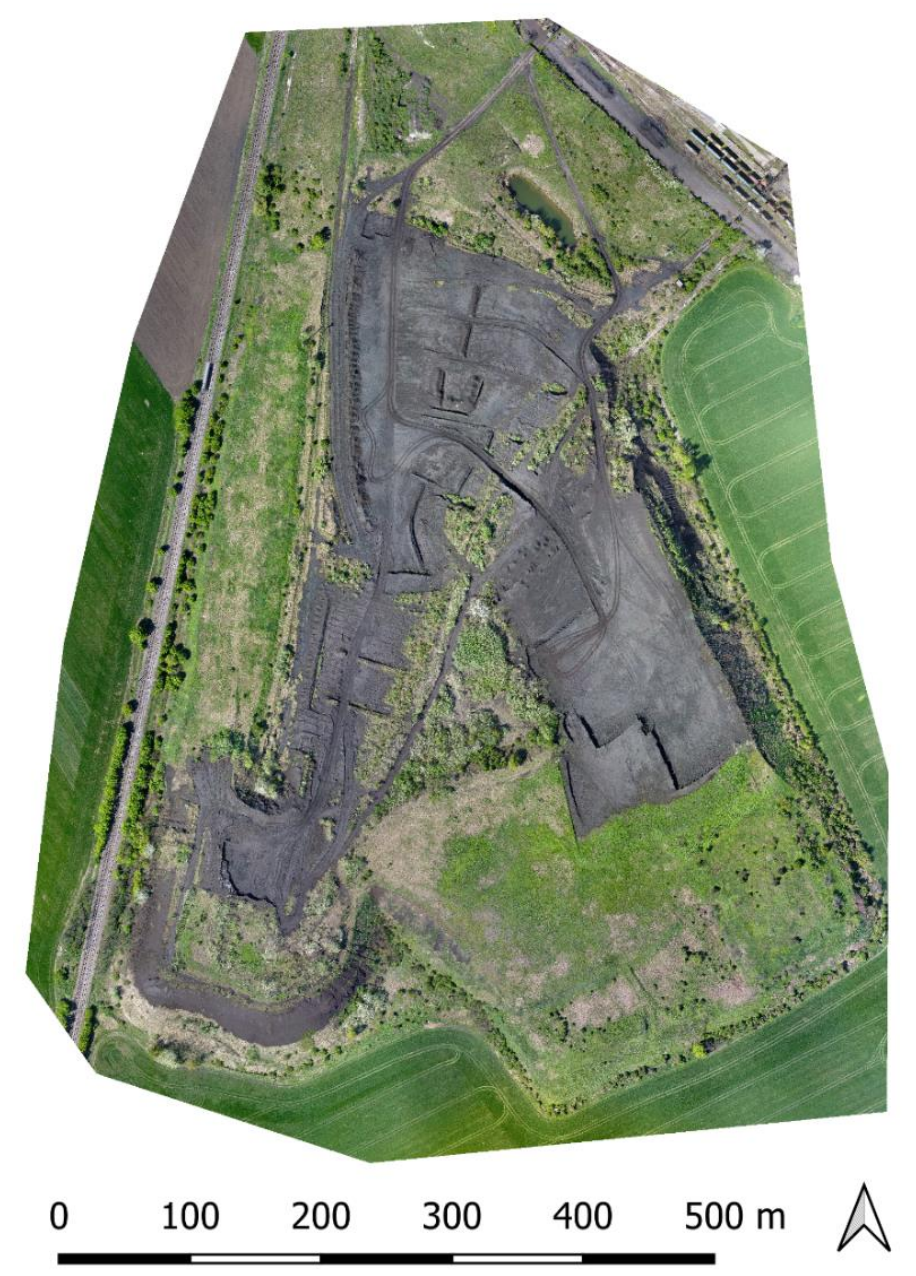

Figure 2. Landfill waste of metallurgical sludge. Source: own orthophotomosaic, 2019.

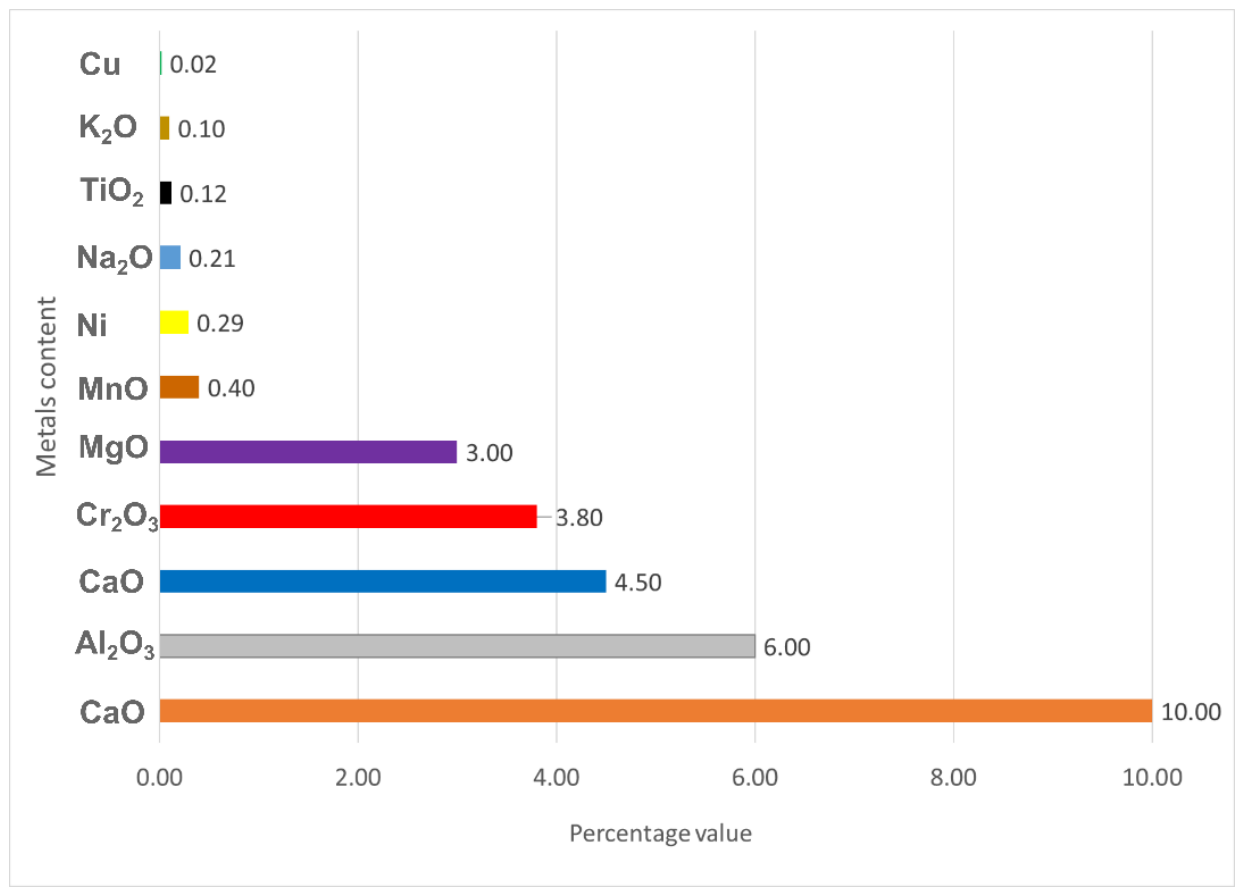

Figure 3. Content of metals in metallurgical sludge (content of iron is 55\%). 
From the aspect of the classification of anthropogenic shapes of relief, we identified the landfill as the accumulation convex form of relief, which was created by the deposition of the metallurgical waste into particular sedimentation sectors in the tailing pond (Figure 4). During landfilling, the sludge was modified with the relevant machineries, and two basic shapes of relief were created, steep slopes and a slightly undulating, which met on a clear terrain edge at the relative height 80-100 m (1994); today, is it only 10-40 m (Figure 5). The landfill is an artificial "Table Mountain", which originated due to the accumulation of the industrial waste (artefact) from nickel production.
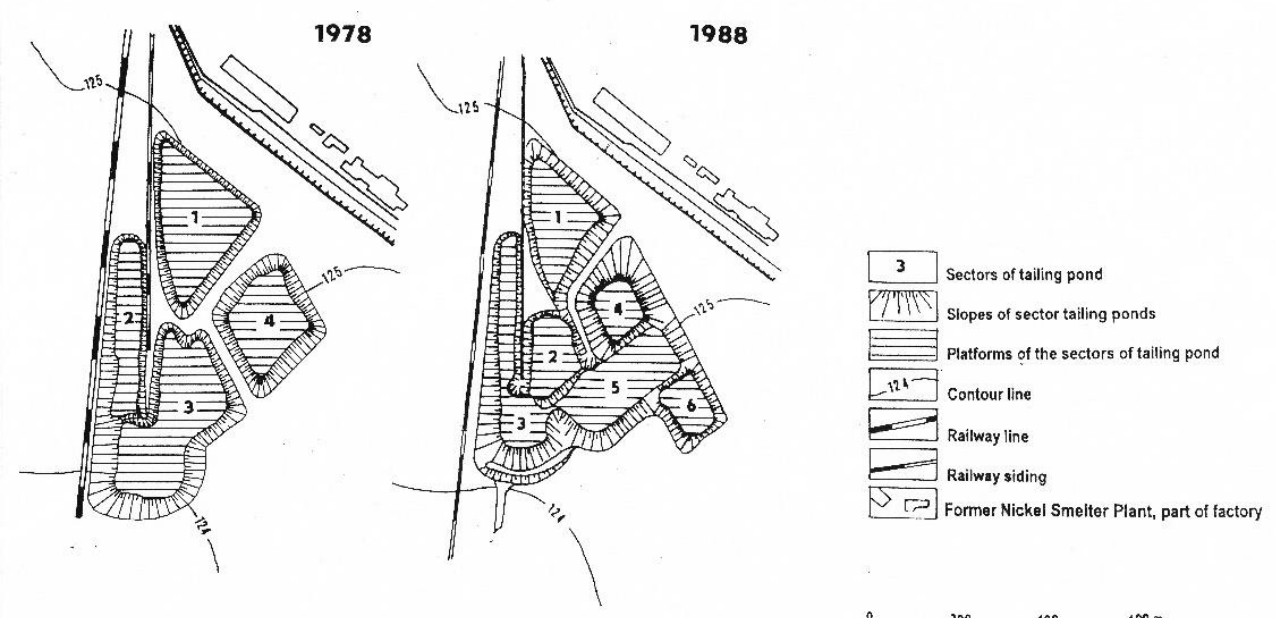

Figure 4. Landfill sludge fields development between 1978-1988.

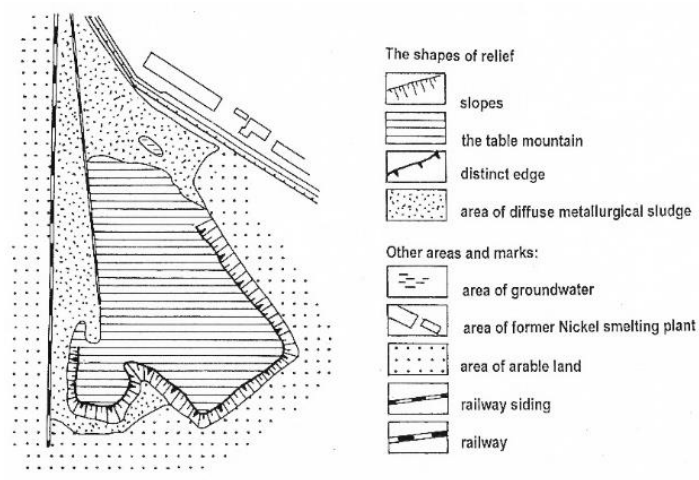

Figure 5. Basic forms of relief on landfill.

According to the development of the relief, the shape of the landfill is in the stage of maturity or premature old age. The absolute age of landfill is 58 years, from the beginning of the deposition of waste from 1963 to 1993. The shapes of relief of the landfill in relation to the continuous deposition of the sludge during the intensive production of nickel changed daily. After the ending of production, the relief shapes are again changing daily (for the last 28 years) due to sludge mining. The geomorphological processes take place in a different landscape milieu, which influence them. In the landfill, these processes act in a non-natural technical porous material with a high proportion of dust particles and powdered sand. We divided the current geomorphological processes that take place on the landfill surface into two groups, the natural processes (processes conditioned by the gravitational force, processes of rainwater erosion on the slopes, and eolian processes) and the anthropogenic processes (Table 1). These processes created the following groups of shapes of relief: the mass wasting forms, the rain rill channel forms, the eolian forms, and the anthropogenic forms. The geomorphological processes participate together in 
the denudation of the surface of the landfill and are typical for the geomorphological conditions of the temperate climate zone and its mild humid subzone of a forest area in the geographical latitude of the Slovak Republic. The zone is characterised by the high seasonality dynamics of the geomorphological processes, also depending on the seasons and anthropogenic geomorphological processes.

Table 1. The geomorphological processes and natural and man-made shapes of the relief on the landfill.

\begin{tabular}{|c|c|c|}
\hline $\begin{array}{l}\text { Exogenous Natural } \\
\text { Geomorphological Processes }\end{array}$ & $\begin{array}{l}\text { Modelling Medium } \\
\text { (Mover-Factor) }\end{array}$ & Natural Shapes of Relief \\
\hline $\begin{array}{l}\text { Gravitational processes, } \\
\text { mass wasting }\end{array}$ & Gravitational force & Creep \\
\hline Rain water erosion on the slopes & $\begin{array}{l}\text { Linearly flowing water on } \\
\text { a slopes }\end{array}$ & Rill channels and gullies \\
\hline $\begin{array}{l}\text { Eolian processes-deflation, } \\
\text { wind transport and } \\
\text { accumulation }\end{array}$ & Wind & $\begin{array}{l}\text { Deflationary cornices and } \\
\text { deflationary witnesses, dust } \\
\text { coatings on the surface of } \\
\text { the soils }\end{array}$ \\
\hline $\begin{array}{l}\text { Exogenous anthropogenic } \\
\text { geomorphological processes }\end{array}$ & Human activity & $\begin{array}{l}\text { Anthropogenic shapes of } \\
\text { relief }\end{array}$ \\
\hline $\begin{array}{l}\text { Landfilling for } 30 \text { years, Mining } \\
\text { of sludge for } 27 \text { years }\end{array}$ & Human activity & $\begin{array}{l}\text { The storage of sludge, roads } \\
\text { for mining mechanisms, } \\
\text { exploration pits and ditches } \\
\text { on the landfill surface, bizarre } \\
\text { shapes after excavator } \\
\text { shovels, etc. }\end{array}$ \\
\hline
\end{tabular}

\subsection{The Geomorphological Processes and Shapes of Relief Conditioned by Gravitational Force (Creep)}

They contribute to the creation of the landforms of mass waste, which shape the steep slopes of the landfill. Gravitational force disrupts the slopes by moving the unconsolidated sediment of metallurgical sludge along their surfaces. The magnitude of the gravitational force depends on the inclination of the slopes and the geological structure of the territory. The shapes of the landforms of mass waste are generally classified according to how quickly and in what amounts the material is moved along the slopes. From this point of view, creep is an extremely slow gravitational process. This is a unique, almost imperceptible, seasonal movement of the metallurgical sludge on the surface of slopes, with a reduction in speed in the depth direction. Creep destabilizes the metallurgical sludge on the surfaces of the steep slopes of the landfill, where the gravitational force pulls the metallurgical sludge down along the slope surface (Figure 6). From a mechanical point of view, creep is a very slow and long process. This is usually the non-accelerated movement of the material, which depends on the inclination of the slope. The speed of movement of the individual particles is very small and is related to the change in their volume due to the alternating heating and cooling, humidification, and drying of the sludge particles. Creep gradually disturbs the surface of the landfill, especially in the south-western part on steep slopes, where the plants have a very shallow rhizosphere. The small, isolated islets of lawns move slowly downwards, and their movement ends at the foot of the landfill. On steep slopes without vegetation, it is possible to observe creep in the form of small one-sided ripples with low peaks, with an orientation according to the slope. The sets of one-sided ripples run in the direction of the contour lines and are almost parallel to them. The speed of movement of the sludge particles is higher on slopes than on the landfill platform. 


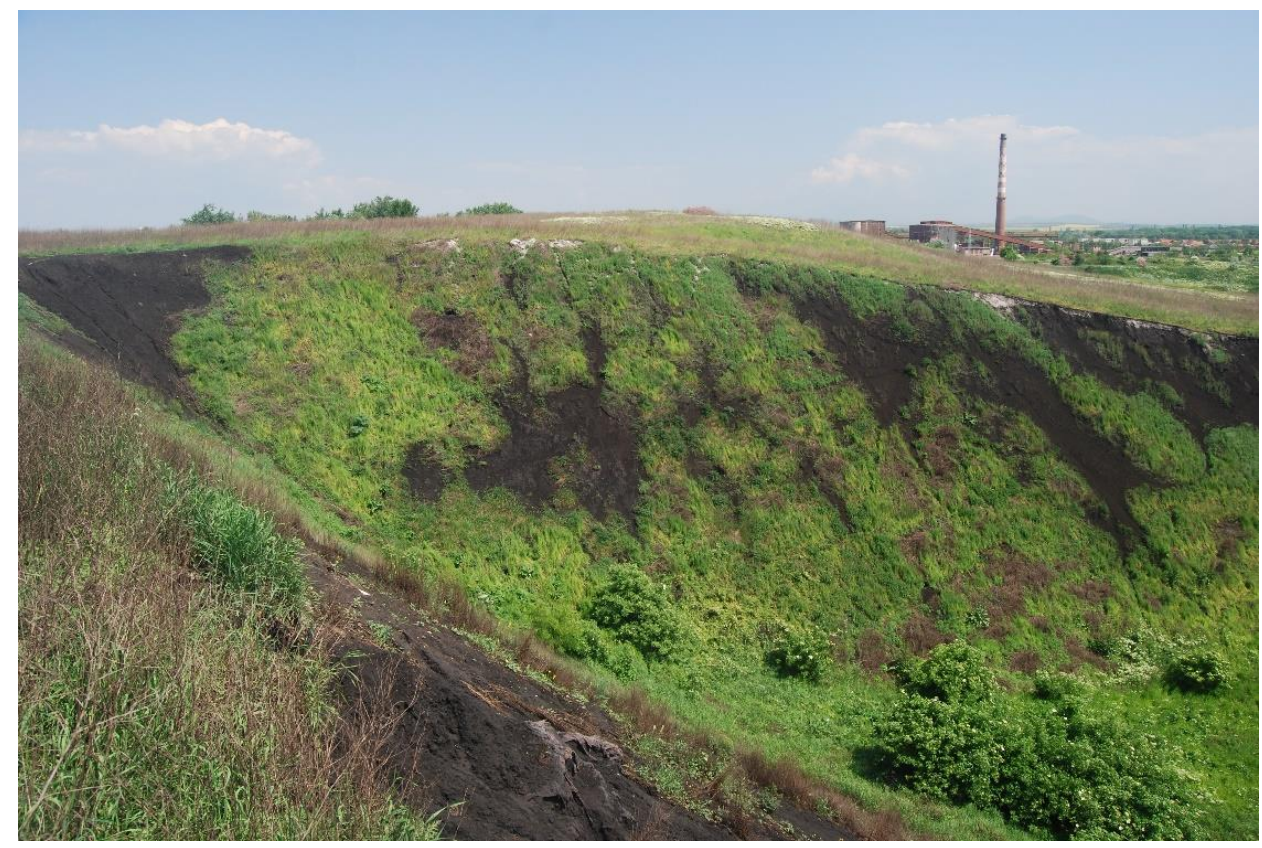

Figure 6. Creep on steep slopes.

3.3. The Geomorphological Processes and Shapes of Relief Conditioned by Vertical Water Erosion on the Slopes (Rill Channels, Gullies)

The modelling medium is linearly flowing water, which creates the two basic relief forms on the slopes of the landfill: rill channels and gullies. The water originates from precipitation and snow melting, but it is mainly from the sprinkling equipment, which was installed to water the surface of the landfill for the purpose of eliminating secondary dustiness. The sprinkling equipment has not functioned since 1983, and so the water does not sprinkle the landfill but flows in the rill channels, according to the inclination of the platform and slopes of the landfill, in the same way as the water from precipitation and the melting of snow. The water erosion on the slopes and platform is manifested as a series of shallow rill channels (depth 6-15 cm, Figure 7).

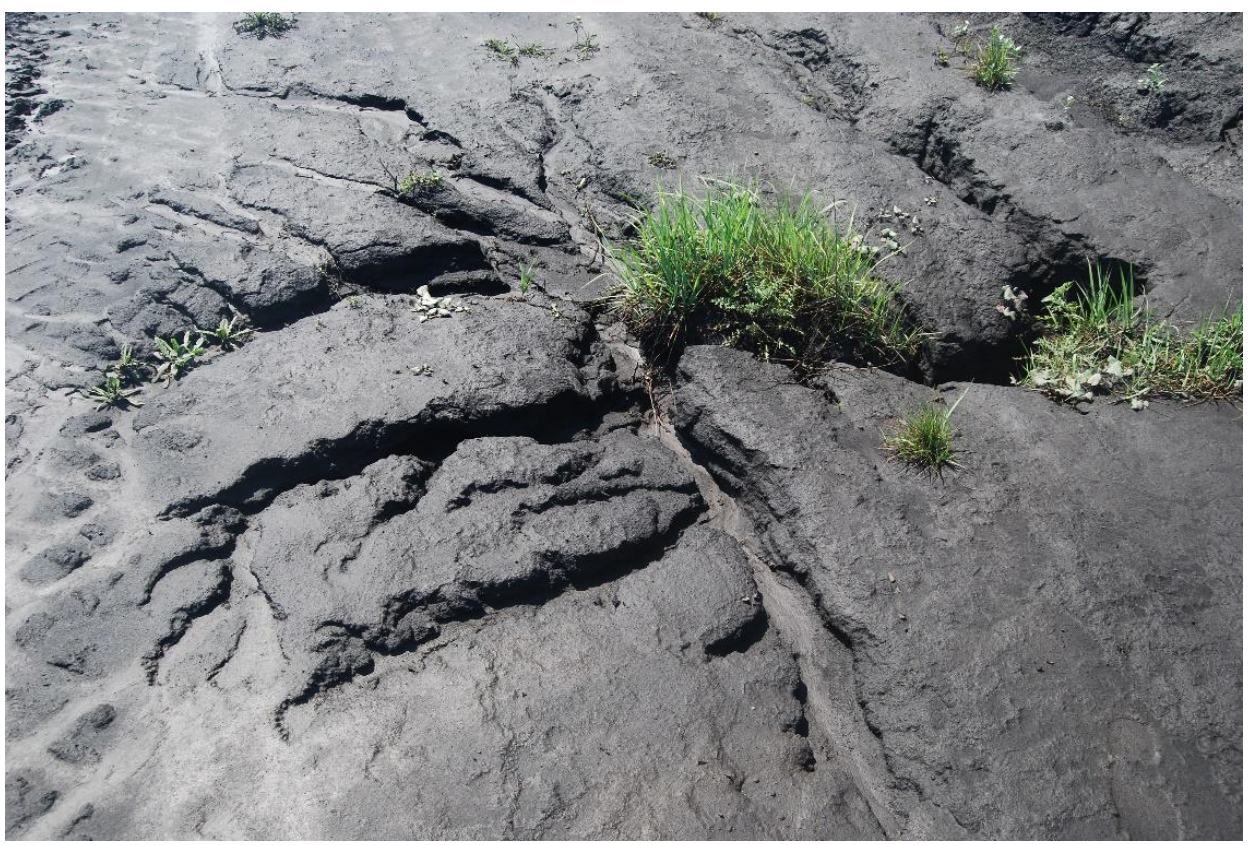

Figure 7. Rill channels. 
The gullies, in comparison with the rill channels, are deeper and wider. Precipitation and water from sprinkling equipment cause the rill channels to deepen and transform into gullies, which have depths of around $60 \mathrm{~cm}$ and more. We observed them in the southern part of the landfill at the slopes, which are oriented to the west and southwest (Figure 8). Some of the gullies have bizarre shapes. Eroded material was deposited below the mouths of gullies at the foot of the landfill as a rinsing cone. During the field research, it was very difficult to determine the share of water that came from precipitation and the share of water from the sprinkling system, as well as their share in the creation of the rill channels and gullies. From the field research, it follows that rill channels and gullies that were dry at the time of mapping (on the landfill, it is not possible to work during rainfall) were largely the result of precipitation activity.

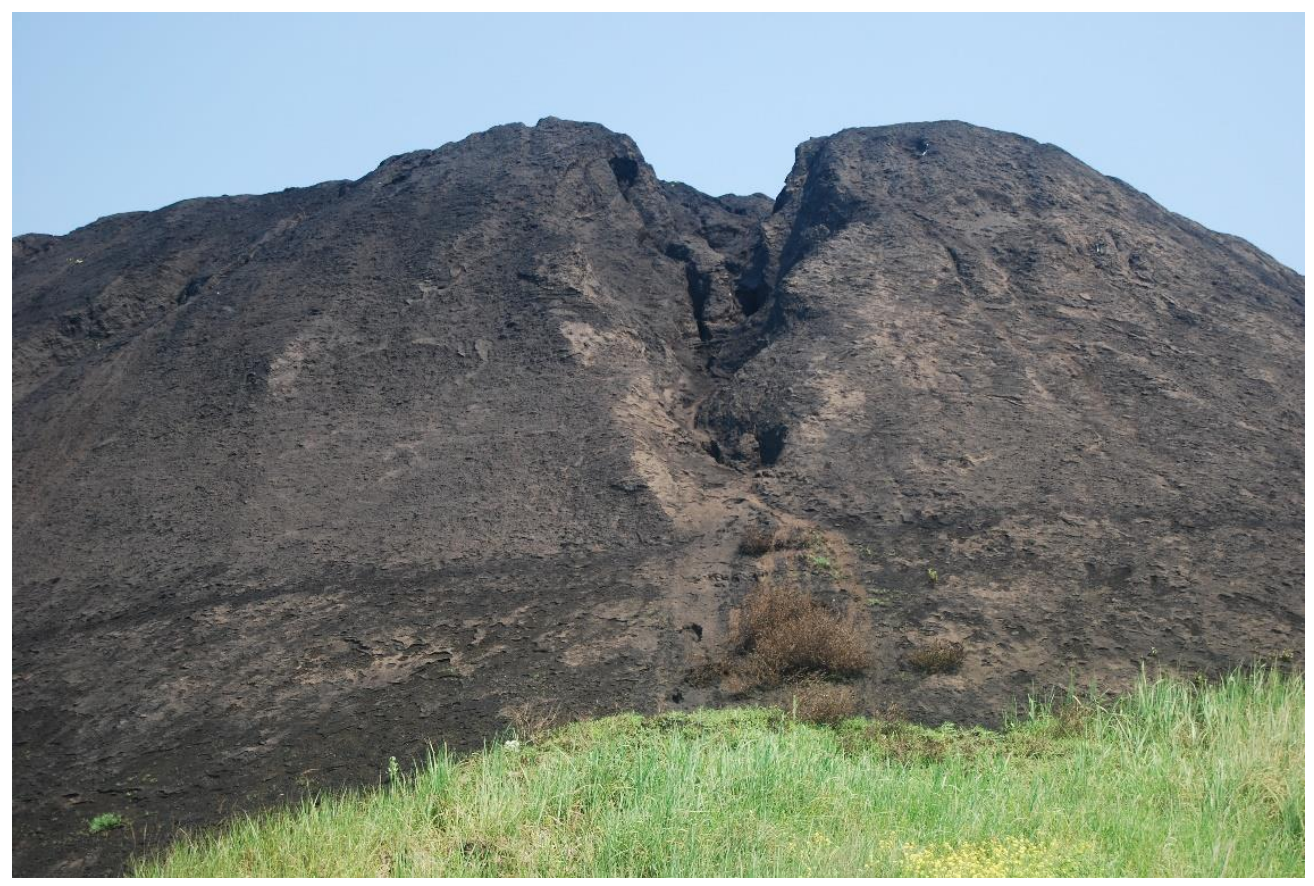

Figure 8. Gully.

The water from the sprinkling equipment is dominant in the processes of water erosion on the landfill, which represent vertical aquatic erosion. This has been confirmed by field research. Along with above-mentioned erosion, raindrops erosion and planar erosion take place on landfill. The raindrops, during precipitation, create many tiny dimples on the surface of the landfill at the parts that are vegetation free. The fall of raindrops to the surface of the metallurgical sludge throws away the individual particles of sludge up to a distance of $1 \mathrm{~m}$. The raindrops' erosion disturbs the surface of the sludge, and so the particles of the sludge are more easily accessible for deflation and other geomorphological processes.

The vertical water erosion, sheet erosion, wind erosion, mass wasting, and other natural and anthropogenic geomorphological processes gradually remove various quantities of sludge from the surface of the landfill and so participate in the denudation of the body of the landfill. The intensity of the water erosion depends on the properties of the sludge (it is a permeable, porous, and loose material), the amount of precipitation and the lengths of the slopes (at the landfill, the slopes are very short), and the existence of vegetation cover. The Danubian Lowland is relatively dry near Sered', with the annual deficit of atmospheric precipitation around $150 \mathrm{~mm}$; this means that all of the forms of water erosion processes are limited here to some extent. 


\subsection{The Eolian Shapes of Relief Conditioned by Wind Activity (Deflationary Witnesses and Cornices, Dust Coatings)}

Wind forms the Earth's surface by the deflation and transport of loose, grained particles of rocks and the accumulation of these particles on certain places. Corrasion (wind grinding) is a process by which the grained particles abrade the surfaces of the shapes of relief. The important factors for the development of the eolian geomorphological processes and shapes of relief are a dry climate, discontinuous vegetation cover, or its absence and a material that can be moved by the wind.

The landfill is located in the warm, dry, and very windy area of the Danubian Lowland. Metallurgical sludge is a bulk and fine-grained material and consists of granular fractions, which can be very easily carried by the wind (the sludge is almost $18 \%$ dust particles of sizes $0.005-0.01 \mathrm{~mm}$ and $35 \%$ particles of sizes $0.02-0.05 \mathrm{~mm}$ ). For the last 58 years, the process of deflation has represented a serious environmental problem for the city of Sered' and its surroundings. The parts of the surface of the landfill on which sludge is mined are constantly getting bigger, and they are the subject of eolian geomorphological processes. From eolian geomorphological processes, the process of deflation prevails here: it takes place on more than $65 \%$ of the surface of the landfill.

The manipulation of the sludge during the mining, but mainly due to wind flow and its force, cause the secondary dustiness. The process of mining loosens the surface of the sludge, which is then the subject of faster deflation. Deflation participates in the formation of some shapes of relief, e.g., the deflationary furrows or gassi, which originated by the deflation of the finest sludge particles by the wind in the south-western direction on the surface of the slopes. The gassi were located on the surfaces of the slopes in the uppermost part of the landfill (sludge mining destroyed them). Metallurgical sludge is an inhomogeneous material, and that fact is related to the technology of production. The sludge contains fine material and layers with larger segments of the tailings (coarse fragments of tailings), which come from imperfectly mechanically processed ore. These segments were uncovered by deflation from fine sludge fractions on the landfill slopes. We call them deflationary witnesses and cornices of deflation (Figure 9).

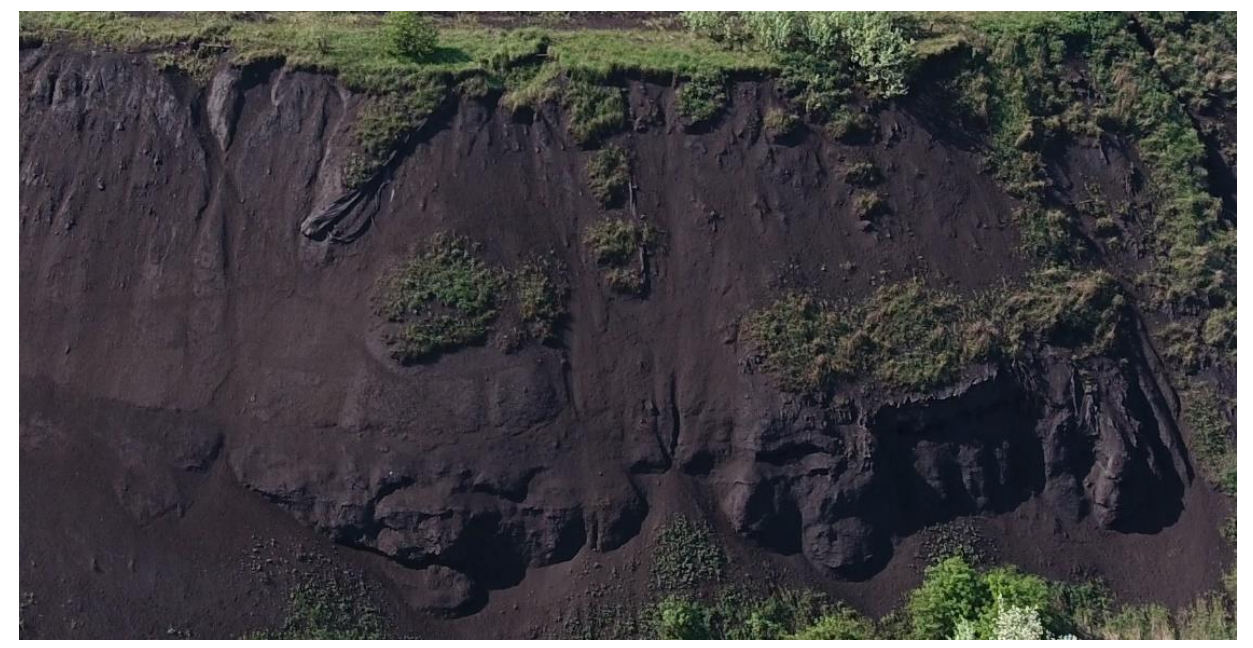

Figure 9. Deflationary witnesses and cornices of deflation.

All the forms of relief mentioned above that take place on the landfill are unstable. Strong deflation occurs predominantly in the spring and autumn months (Figure 10). The wind at first carries the dust from the sludge away from the surface of landfill, which then subsequently rises into the higher layers of the atmosphere in the form of aerosols and is transmitted over large distances. Traces of this dust are found in the Danubian Plain up to $50 \mathrm{~km}$ from the landfill. 


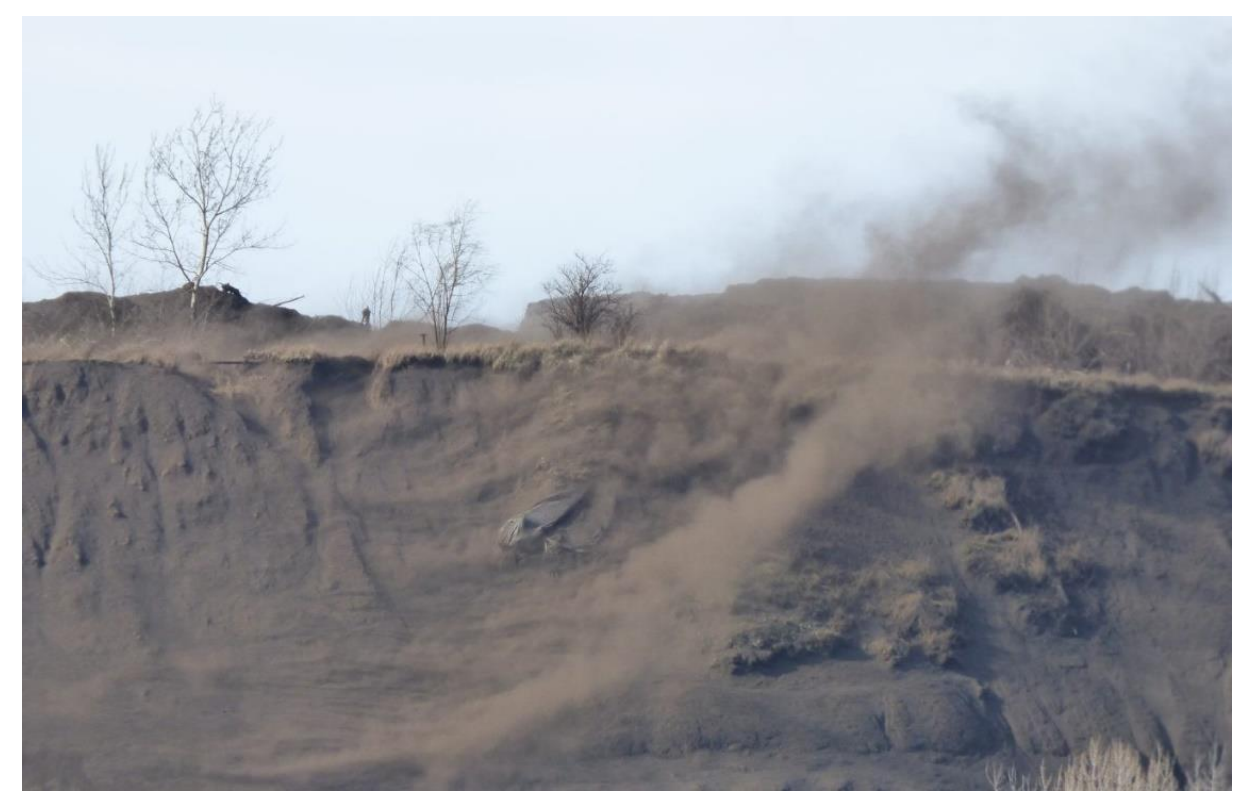

Figure 10. Windstorms can carry dust over long distances (March 2020). Source: www.seredonline.sk.

The field research did not confirm the occurrence of visible shapes of eolian accumulation in this space, as the dust sediment is a very fine material and is dissipated on a large space of planar relief of the Danubian Lowland. Deflationary dust creates only dust coatings, which cannot be exactly spatially identified. They are only very thin layers of dust on the surface of the soils. The process of the dust deflation from polymetallic sludge has taken place for 58 years and is a direct cause of the contamination of the environment and the damaging of the health of the population. The deflation annually removes about 20,000 tons of dust from the landfill [21]. In 58 years, this adds up to approximately 1-1.2 million tons. According to weather conditions (wind forces), sludge was dissipated over an area of approximately $5000 \mathrm{ha}$, but the 0.01 to $0.05 \mathrm{~mm}$ dust particles spread over a larger area. The metallurgical sludge is a toxic and carcinogenic material. For example, on the measuring device placed next to the Health Centre in the town of Sered' (Figures 11 and 12), the dust sediment contained $291 \mathrm{~g} \cdot \mathrm{m}^{-2}$ of heavy metals (manganese, zinc, cobalt, cadmium, chromium, nickel, and lead).

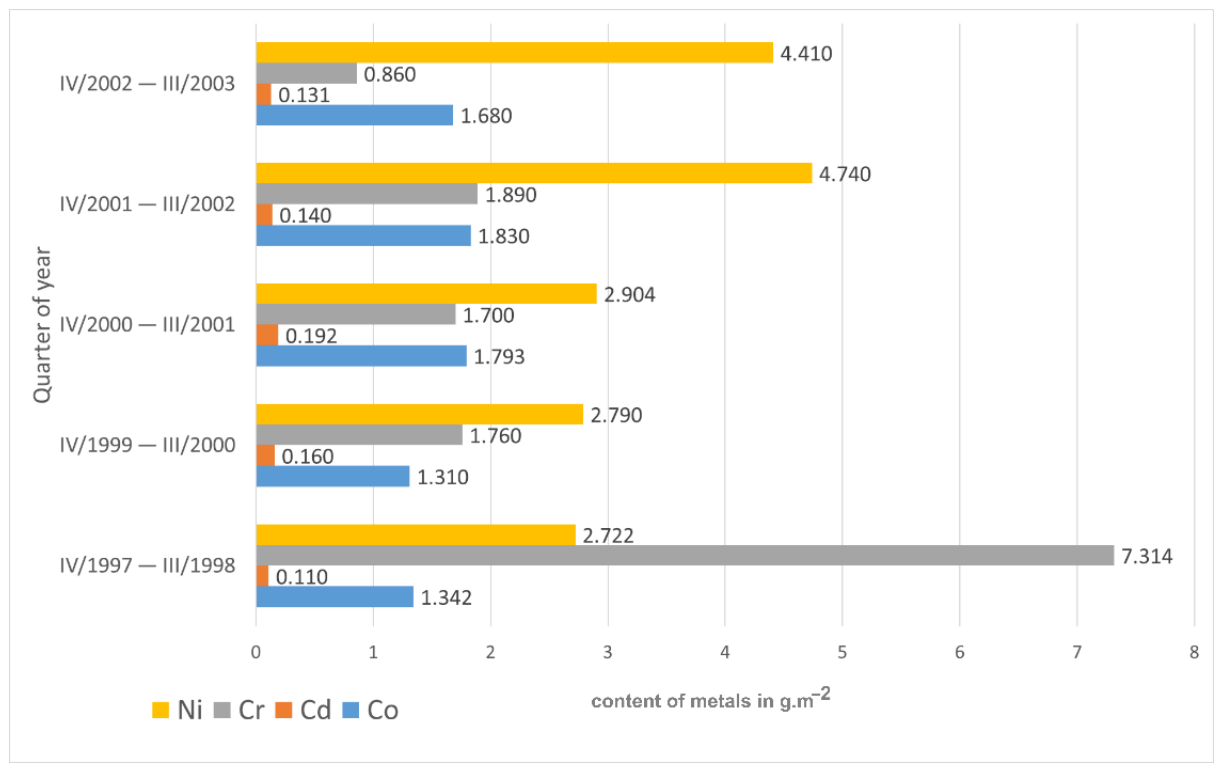

Figure 11. Dust sediment containing heavy metals (next to Health Centre). 


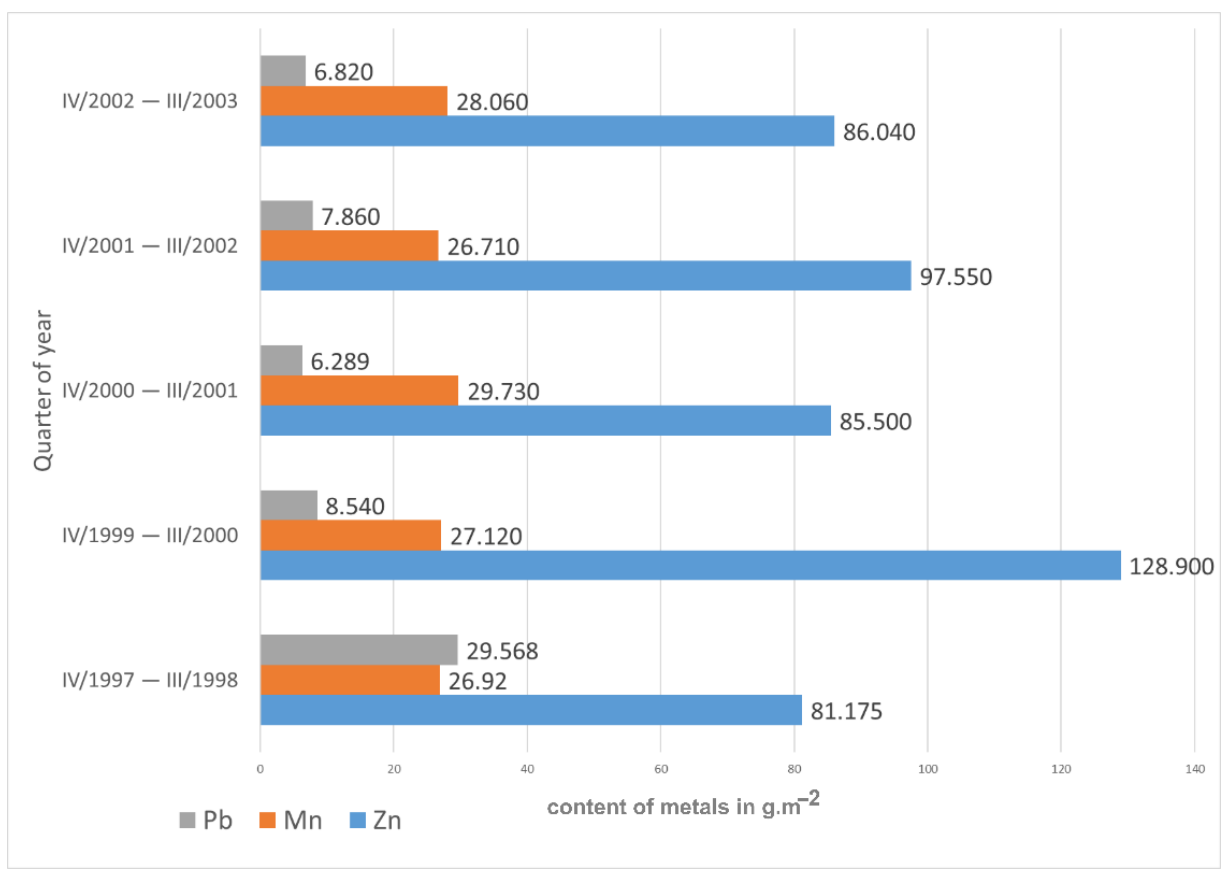

Figure 12. Dust sediment containing $\mathrm{Pb}, \mathrm{Mn}$, and $\mathrm{Zn}$ metals (next to Health Centre).

3.5. Anthropogenic Shapes of Relief Conditioned by Human Activity (Shafts, Depressions after the Excavator Shovels, Etc.)

To begin, it is necessary to say that the anthropogenic shapes of relief arise in connection with mining the secondary raw material on the landfill of metallurgical sludge, which is an anthropogenic artificial form of relief. The landfill is a private property (since 1994), and its owners have mined the metallurgical sludge there for the last 27 years. Direct anthropogenic geomorphological processes associated with mining belong in this group of processes. As a consequence of this mining, the anthropogenic shapes of relief are not stable, and in some places, they change very rapidly (almost daily); thus, mining changes the physiognomy of all of the body of the landfill. We processed a map of the shapes of relief for the year 2019 (Figure 13).
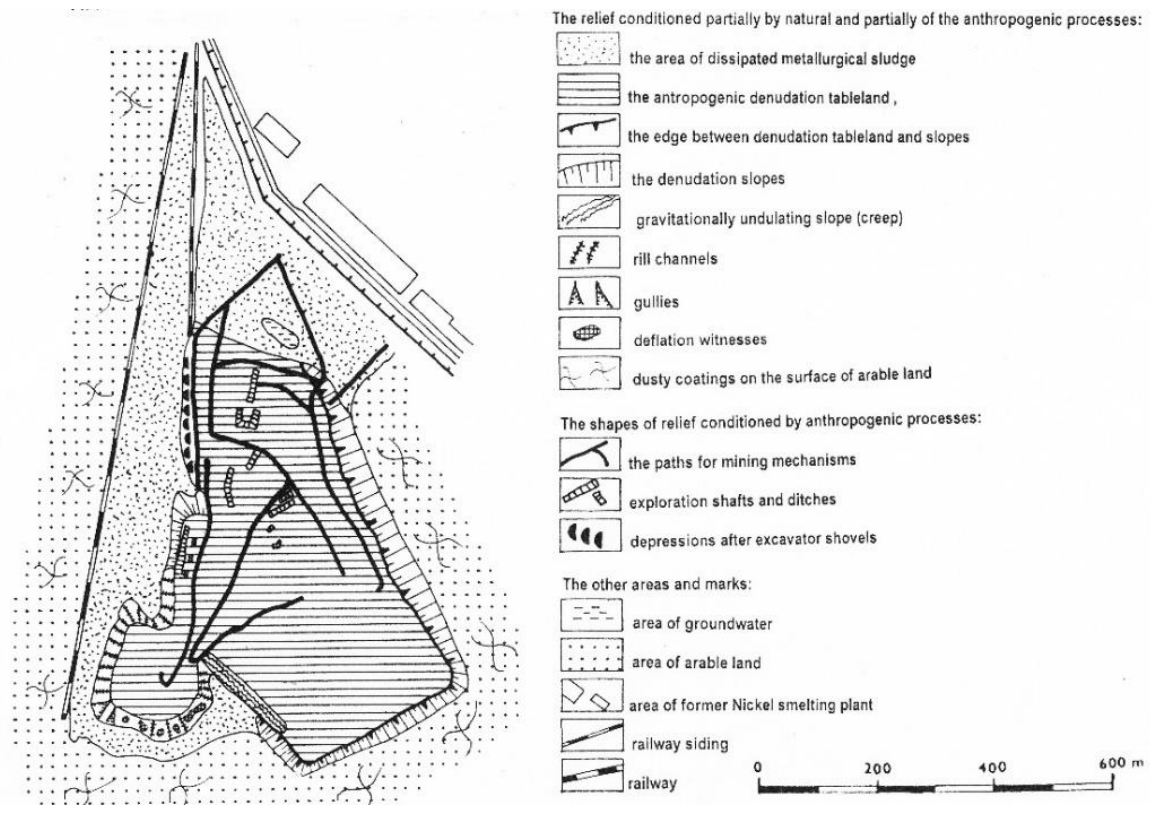

Figure 13. Shapes of relief. 
The anthropogenic mining process considerably affects all the natural geomorphological processes mentioned above. The rainwater erosion and sprinkling water erosion (rill channels, gullies) on the slopes and the mass wasting processes relocate the sludge mainly to the foot of the landfill. Deflation relocates the sludge to more distant areas up to $50 \mathrm{~km}$ from the landfill. The amount of sludge in the landfill decreases through mining but also through the harmful natural eolian geomorphological process of deflation. All geomorphological processes participate in the denudation of the entire body of the landfill by its own modelling medium. For better orientation, we created an elevation map (Figure 14).

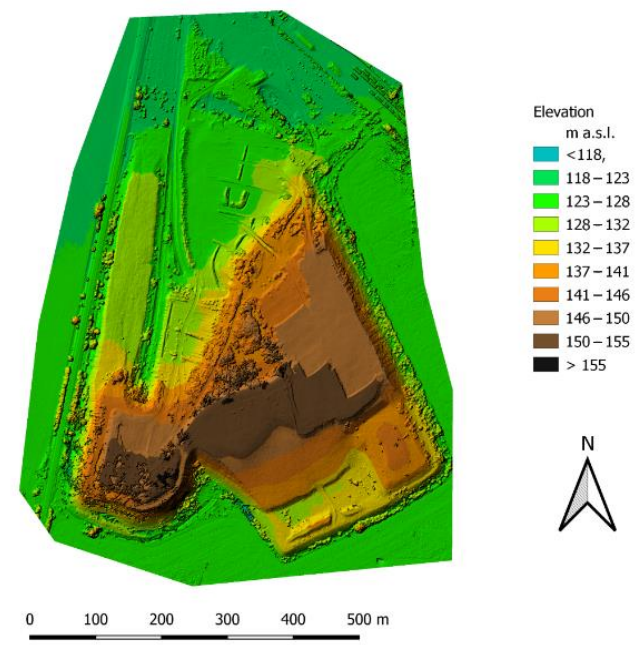

Figure 14. Elevation map.

The anthropogenic process consists of preparing paths for the mining of the sludge for the purpose of shifting it in the direction of mining machines. Another process is the digging of exploration shafts in the sludge and sampling in order to obtain information on the quality of the sludge for mining. The bizarre shapes of anthropogenic erosion that occur after mining processes belong in this group. Most of them have an irregular to strange shape (e.g., the depressions after the excavator shovels, etc., Figure 15). An advantage for mining is that the mining mechanisms do not become immersed in the sludge, because the current landfill does not contain a liquid component.

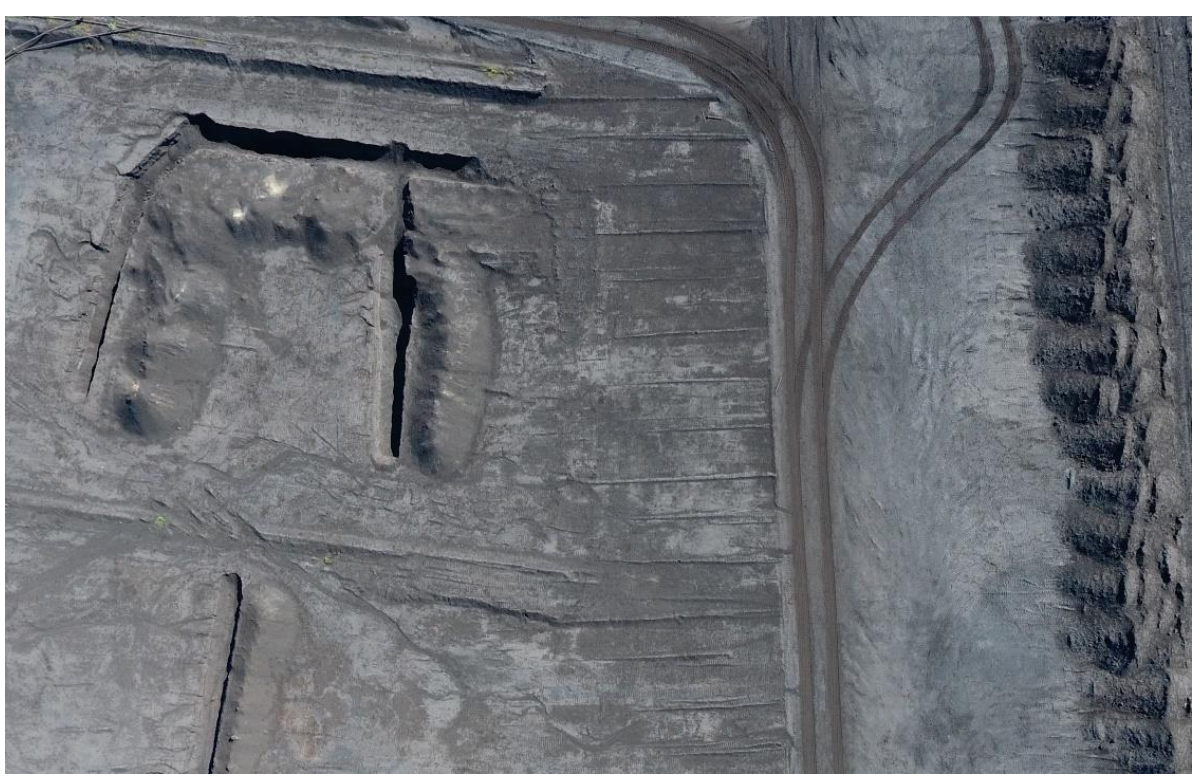

Figure 15. Anthropogenic forms of relief on plateau of landfill. 


\section{Discussion and Conclusions}

The object of our research was the landfill of metallurgical sludge or the anthropogenic industrial convex form of relief, which originated through the accumulation of waste during the 30 years of the production of nickel at the former smelter plant in Sered' (1963-1993). It is an artificial strange element of relief in the cultural landscape of the Danubian Lowland. After the ending of production in 1993, the landfill was not remediated, and its development continues through the denudation of the surface through natural and anthropogenic geomorphological processes today, i.e., for $30+28$ years. The basic aim of our research was to analyze the shapes of the relief that originated on the landfill and at the same time identify the accompanying geomorphological processes that are ongoing there, what they cause, and why they cannot be stopped. From the field research, it follows that the current landfill surface is shaped, on the one hand, by anthropogenic geomorphological processes related to mining secondary raw materials and, on the other hand, by the natural geomorphological processes inherent in the given morphoclimatic zone in terms of the geographical position of the landfill. Both groups of geomorphological processes are dangerous to the environment and endanger living organisms and the health and quality of life of the population. The surface mining increases the effects of supporting nearly all the natural geomorphological processes, especially deflation. The geomorphological process of deflation in the town of Sered' threatens the health of more than 20,000 inhabitants, as well as the inhabitants in the villages Dolná Streda, Váhovce, Vel'ká Mača, and Gán̆, and devastates all components of the environment. This condition (at different intensities, according to the wind force) has lasted more than half a century (58 years). On the basis of our analysis of the sludge, we note that the metallurgical sludge contains particles of heavy metals (lead, chromium, iron, cobalt, nickel, etc.). The research suggests that shapes of relief created from industrial technological material are linked dynamically through natural and anthropogenic geomorphological processes with the surrounding landscape. In our case, the metallurgical sludge, through the natural geomorphological process of deflation, is shifting into a large part of the territory of the Danubian Lowland, in an area of almost 5000 ha. From this, it is clear that the landfill requires increased attention.

The research of anthropogenic forms of relief from the perspective of geomorphological processes is important for two reasons. On the one hand, it is important because their number and diversity are steadily increasing in the context of population growth. On the other hand, many of them become the cause of catastrophic phenomena in the densely populated areas of cultural landscapes. In the domain of the anthropogenic forms of relief, from the aspect of bizarre and hazardous structures, the industrial and mining shapes of relief have a significant position. The landfill has been a private property since 1994 . According to the purchase-sales contract, the owners committed to greening the landfill by 2006 and removing it by 2009, which has not happened. The company has performed the mining of metallurgical sludge continuously for 28 years and ignores the demands of the citizens and local government for the remediation of the landfill, despite the law on environmental burdens, which has been in force since 2011.

It is very difficult to draft restrictions that would apply to the landfill itself. The fact that it is private property ties the hands of researchers and, to some extent, both local government and state administration. It is necessary to apply the laws of the Slovak Republic on nature protection and environmental burdens. According to our research, it is necessary to stop mining at the landfill and, Based on detailed analyses of metallurgical sludge in the entire landfill, it is necessary to propose greening. This process would seal deflation and preserve the landfill for future generations as a surface deposit of secondary raw materials.

Author Contributions: Conceptualization, E.M. and M.M.; methodology, E.M., J.V. and M.M.; software, M.M.; validation, E.M., M.M. and M.B.; formal analysis, J.V., M.M. and E.M.; investigation, E.M., M.M., V.S. and M.B.; resources, E.M., V.S. and M.B.; data curation, E.M.; writing-original draft preparation, E.M.; writing-review and editing, E.M. and M.M.; visualization, M.M.; supervision, E.M.; project administration, E.M. and J.V.; funding acquisition, E.M. All authors have read and agreed to the published version of the manuscript. 
Funding: This work was supported by the Scientific Agency of the Ministry of Education, Science, Research, and Sport of the Slovak Republic VEGA—Project No. 1/0299/19 and VEGA No. 1/0059/19. Work was also supported by the Slovak Research and Development Agency under the Contract No. APVV-18-0185.

Institutional Review Board Statement: Not applicable.

Informed Consent Statement: Not applicable.

Data Availability Statement: We do not have any used data from publicly archived datasets.

Conflicts of Interest: The authors declare no conflict of interest.

\section{References}

1. Szabó, J.; Dávid, L.; Lóczy, D. Anthropogenic Geomorphology: A Guide to Man Made Landforms; SPRINGER Science \& Businees Media B.V.: Dordrecht, The Netherlands; Heidelberg, Germany; London, UK; New York, NY, USA, 2010.

2. Cooper, A.H.; Brown, T.J.; Price, S.J.; Ford, J.R.; Waters, C.N. Humans Are the Most Significant Global Geomorphological Driving Force of the 21st Century. Anthr. Rev. 2018, 5, 222-229. [CrossRef]

3. Szypula, B. Quantitative Changes of Anthropogenic Relief over the Last 100 Years in the Silesian Upland (South Poland). Z. Geomorphol. 2014, 58, 175-183. [CrossRef]

4. Klimaszewski, M. Geomorfologia, 6th ed.; Wydawnictwo PWN: Warszawa, Poland, 1981.

5. Demek, J. Obecná Geomorfologie; Academia Praha, ČSAV: Praha, Czech Republic, 1987.

6. Lacika, J. Geomorfológia; Technická Univerzita vo Zvolene: Zvolen, Slovak, 1997.

7. Dzurovčin, L. Geomorfológia. Vysokoškolská Učebnica; Prešovská univerzita: Prešov, Slovak, 2000.

8. Goudie, A.S. The Human Impact on the Natural Environment: Past, Present, and Future; Wiley Blackwell: Oxford, UK, 2005.

9. Migoń, P. Geomorfologia; Wydawnictvo naukowe PW: Warszawa, Poland, 2009.

10. Kirchner, K.; Smolová, I. Základy Antropogénni Geomorfológie; Univerzita Palackého: Olomouc, Czech Republic, 2010.

11. Hronček, P.; Rybár, P.; Weis, K. Kapitoly z Antropogénnej Geomorfológie; Edičné stredisko/AMS: Košice, Slovak, 2010.

12. Čech, V.; Krokusová, J. Antropogénna Geomorfológia; Vydavatel'stvo prešovskej univerzity v Prešove: Prešov, Slovak, 2013.

13. Fels, E. Der Mensch Als Gestalter Der Erdoberfläche. Petermans Geogr. Mitt. 1934.

14. Podgórski, Z. Antropogeniczne Zmiany Rzežby Terenu Na Obszarce Polski. Prz. Geogr. 2001, 73, 37-56.

15. Michaeli, E.; Boltižiar, M. Selected Localities of Environmental Loads in the Slovak Republic. Geogr. Cassoviensis 2010, 2, 114-119.

16. Hronček, P.; CHOMOVÁ, L.; CHOMA, A. Charakteristika a Prognózy Vývoja Banských Háld v Juhoslovenskej Hnedouhol'nej Panve z Hl'adiska Ich Geneticko-Morfologických Vlastností, Pôd a Vegetácie. Geogr. Štúdie 2001, 8, $226-232$.

17. Remondo, J.; Soto, J.; González-Diéz, A.; de Terán, J.R.D.; Cendrero, A. Human Impact on Geomorphic Processes and Hazards in Mountain Areas in Northern Spain. Geomorphology 2005, 66, 69-84. [CrossRef]

18. Michaeli, E.; Solár, V.; Maxin, M.; Vilček, J.; Boltižiar, M. The Nature of the Technosols on the Waste from Nickel Production. Sustainability 2021, 13, 406. [CrossRef]

19. Mazúr, E.; Lukniš, M. Geomophological Subdivisions of Slovak Republic; Atlas of SR: Bratislava, Slovakia, 1980.

20. Michaeli, E.; Boltižiar, M.; Ivanová, M. Geoecological Structure of the Dump of Technological Waste (Fe-Concentrate) et Sere'. Folia Geogr. 2009, XLIX, 180-197.

21. Paulech, C.; Šály, A. Základný Biologicko-Ekologický Prieskum v Oblasti Haldy Lúženca v Niklovej Hute v Seredi; Záverečná Správa Ústavnej Úlohy č. Ú-2; Ústav experimentálnej biológie a ekológie SAV: Bratislava, Slovakia, 1983. 